\title{
IMPROVEMENT OF AIS FOR CONTROL OF THE BUSINESS PROCESS OF PUBLISHING SCIENTIFIC JOURNALS
}

\author{
O. Yu. Sakaliuk ${ }^{1}$ \\ ${ }^{1}$ Odessa National Academy of food technologies, Odessa \\ E-mail: sakaliuk.olexiy@ gmail.com
}

Copyright (C) 2014 by author and the journal "Automation technological and business - processes". This work is licensed under the Creative Commons Attribution International License (CC BY). http://creativecommons.org/licenses/by/4.0/

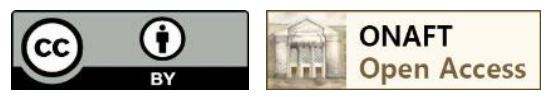

Abstract: We consider business process automation publishing scientific journals. It describes the focal point of publishing houses Odessa National Academy of Food Technology and the automation of business processes. A complex business process models publishing scientific journals. Analyzed organizational structure of Coordinating Centre of Scientific Journals' Publishing ONAFT structure and created its model. Software "CCSJP Manager" was analyzed and found in it "weak areas." Automated information system was modernized. The economic feasibility of the software development was substantiated, and the definition of efficiency. The developed software will accelerate the development of scientific periodicals ONAFT, which in turn improve the academy ratings at the global level, improve its image and credibility.

Key words: Business process, process model, BPMN notation, automated information system, webcam, adaptive layout, effectiveness of development, neural network.

Today, more enterprise managers are considering the use of information technology as an opportunity to improve the efficiency of the business process. Operational control of the company's activities, performance and attitude of each employees to ensure accelerated growth in the development process, the ability to effectively expand personnel. An important advantage of the automation system is high speed.

Recently there is a tendency to develop information systems based on database management systems (DBMS), which contain relevant data libraries and core software, that a particular algorithm provides access depending on user rights and tasks that lie ahead.

There are various information systems that provide management staff. Particularly, there is software «Evernote» to create and store notes [1]. There is also an organizer for personal use and teamwork «LeaderTask» [2]. But these programs do not completely solve this problem, standing in the automation of business process publishing scientific journals, therefore it was decided to develop its automated information system, that would meet the needs of employees coordination center of the publishing.

Odessa National Academy of Food Technologies today is not only a place to gain knowledge of students, but also a factor of science as such. The development of scientific schools always due to the need of research publications. For this purpose, at the Odessa National Academy of Food Technologies was founded 9 of periodic scientific and industrial publications. For the organization of equal development of all periodicals Odessa National Academy of Food Technology and bring them to international standards publishing scientific periodicals in early 2014 was based Coordinating Centre of Scientific Journals' Publishing.

Coordinating Centre of Scientific Journals' Publishing of Odessa National Academy of Food Technologies (CC SJP ONAFT) is a center of assistance, promoting and support of scientific periodical journals and scientific research activities of ONAFT. The center was established in 2014 aiming at equal development of all academy editions and improving scientometric indexing of academy scientists. CC SJP ONAFT has qualified specialists in scientometrics and in promotion of scientific journals in the world.

At this stage of computerization in all spheres of human life is very acute question of automation management.

The automated system of enterprise management (ASEM) - a set of software, technical, information, linguistic, organizational and technological means and qualified personnel actions designed to meet the challenges of planning and management of various types of enterprises.

Automated control systems now required to optimize and improve the efficiency of management and certain other personnel services company. 
Business process of publishing scientific journals of Odessa National Academy of Food Technologies can be represented as an artificial neural network. That is, it is a model based on the principle of operation of biological neural networks - networks of nerve cells of a living organism. It is a system of connected and inter-related processes.

On the Fig.1 you can track the success of progress the scientific journal, at the inputs of the neural network we have information on the basic requirements of a successful journal. If these requirements correspond to journal, he can join the database indexing and abstracting. To join the database, each with its own requirements.

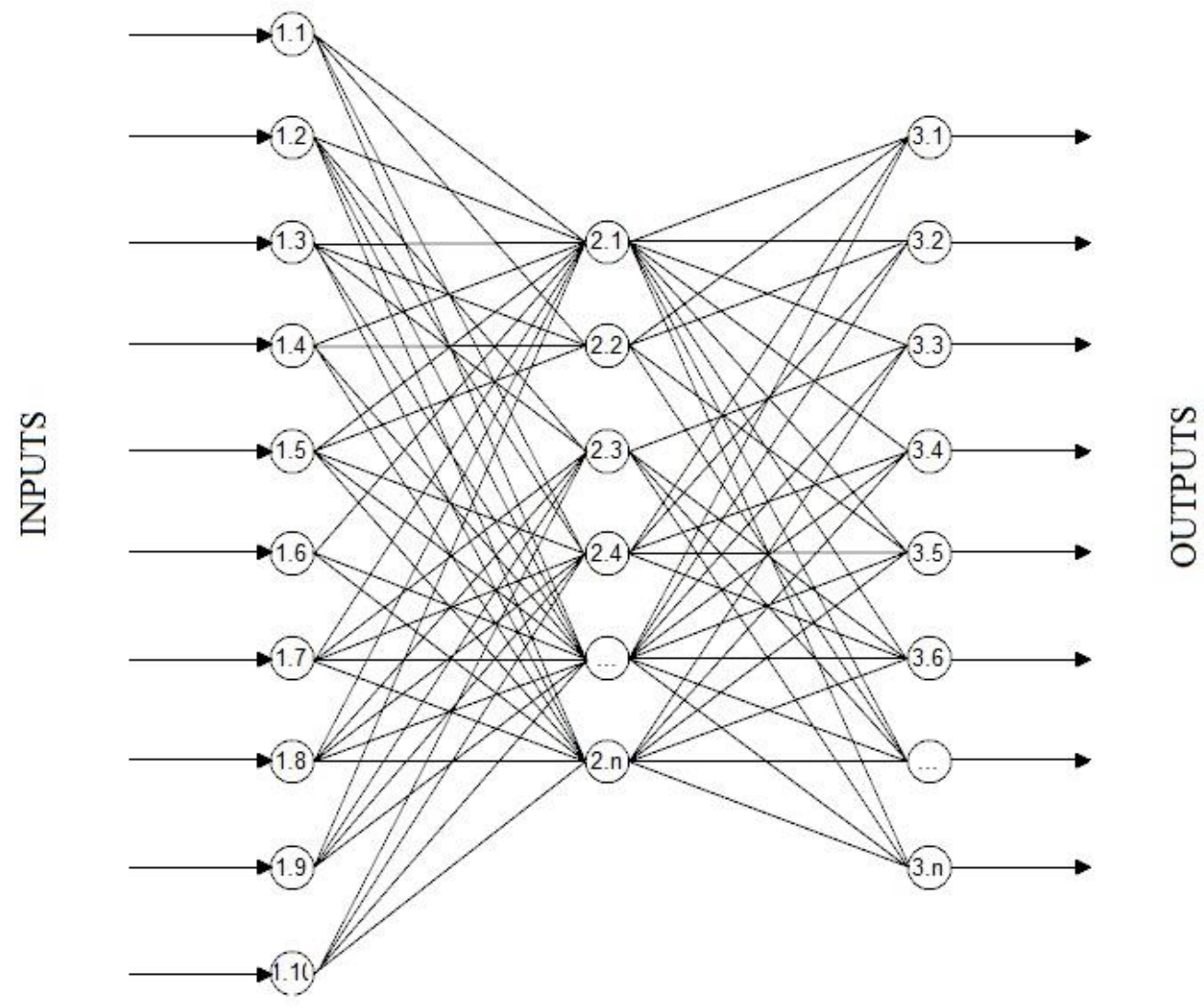

1.1 - status of Higher Attestation Commission; 1.2 - international editorial board; 1.3 - a license agreement with the authors of articles; 1.4 - articles in English; 1.5 - ISSN(print); 1.6 - ISSN(online); 1.7 - Creative Commons license; 1.8 - Iнmepнеm website on your own domain, host; 1.9 - multilingual site; 1.10 - latest news; 2.1 -journal 1; $2 . n$ - journal n; 3.1 - base 1; 3.n-base $n$

Fig.1 - The neural network of the business process of publishing scientific journals

In 2016 was developed the automated information system "CCSJP Manager" with the view of making a better results of work and quality of work performed by employees CCSJP ONAFT. For what was studied in detail the business process of publishing scientific journals. The research base for the study of which is the Coordinating Centre of Scientific Journals' Publishing of Odessa National Academy of Food Technologies. Business process was simulated in BPMN notation. Modeling business processes allows to analyze not only how the company works as a whole as it interacts with external organizations, customers and suppliers, but also as an organized activity for each individual workplace.

The result is automation improve the quality of databases - the accuracy, completeness, speed, consistency.

The developed software has a user-friendly interface and adapts to each employee individually, which is very convenient for work because they do not need to pay extra attention to things in your box. The program is a handy task manager with the ability to monitor the implementation of all tasks. Head of unit at any time can check the employment and workload any of their employees and assess the course of the process.

На якість управління організацією впливає безліч факторівMany factors affect the quality of management of the organization, properly constructed structure and division of labor, the availability of the necessary resources, modern technology is one of the most important. The ratio of staff to work, and the leader of the organization influences the management efficiency.

Efficiency describes the result of any activity.

Effective management is derived from the achievement of enterprise goals and objectives.

Improvement, development and competent construction management system helps achieve high performance in the activities and take a leading position in the market. 
There have been upgrades software to improve the efficiency of business process management business process of publishing scientific journals, namely:

- redesigned software;

- adaptation software for mobile devices and tablets;

- development management table with the possibility of charting;

- development of the automatic generation of reports on executed work;

- fixes a number of bugs and flaws of the old software.

The main task of design software - integration of all information blocks and the formation of by a pleasant experience. Basically, the design shapes the overall style of the software helps the visitor to understand at a glance that it is waiting. Good design - a discreet, unobtrusive design that does not distract the visitor from the main - provided by the target information.

As you know, meet on clothesand this means that the reliability of your organization will be judged by its design website and software. Competent design online resource reflects the individual style of the company, helps it stand out among competitors.

Progress does not stand still and every day in our lives more and more includes new technologies. This technology allows you to create pages able to adapt to any screen size ranging from mobile screen and ending with widescreen monitors. Basically, the adaptation of the software is due to compression and rebuilding layout depending on the width of the device.

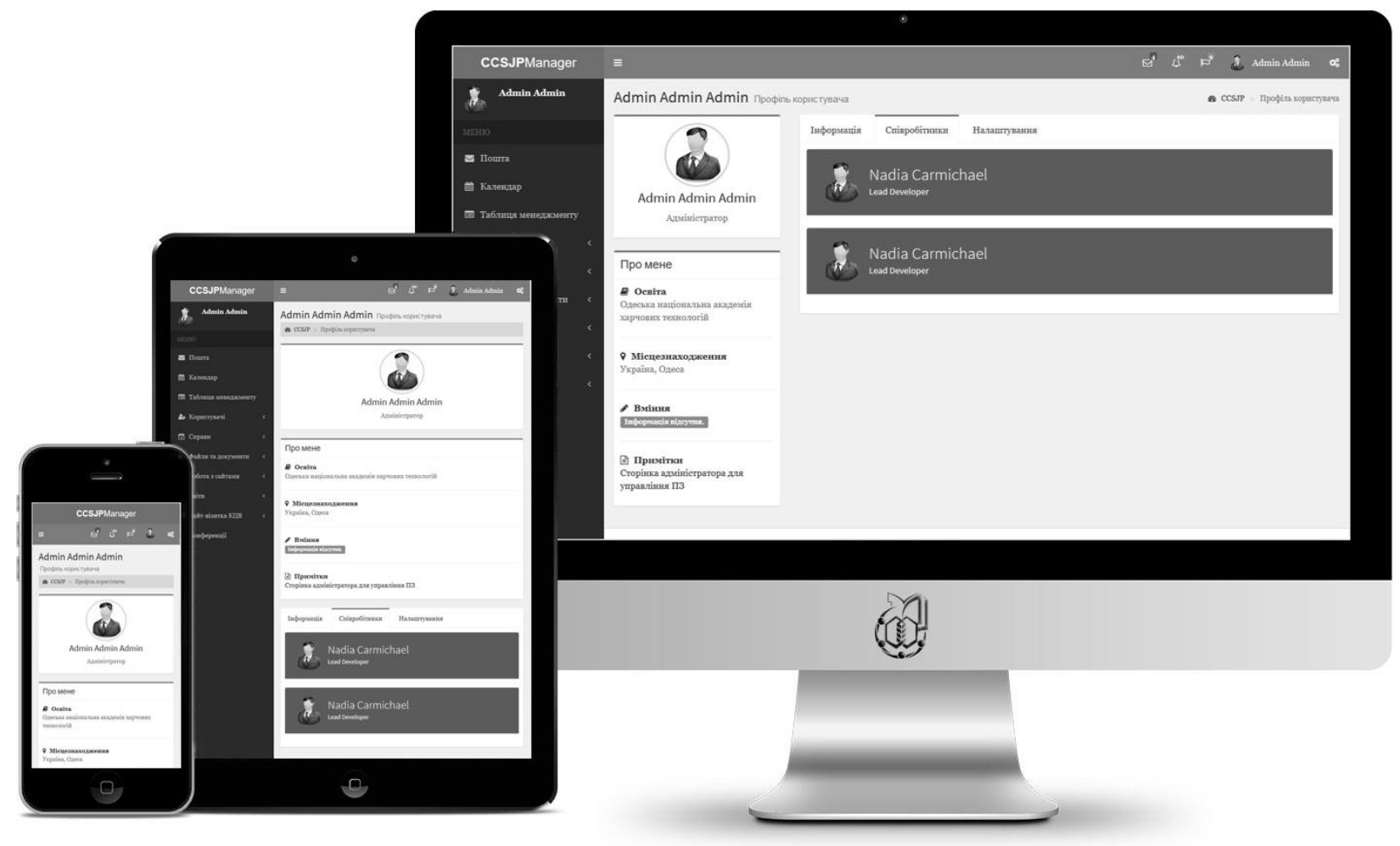

Fig.2. Adaptive layout of the software "CCSJP Manager»

Adaptive layout downside is that the process of creating software takes much longer time than if two separate versions were created, file size is larger. But more advantages: general content of all versions of the software - ease of editing content; simple software upgrade, bringing it in line with new requirements and standards, technical specifications, quality software.

Using adaptive layout software "CCSJP Manager" lead to the fact that employees of the center will work not only in their workplace. Moving away from the workplace employee immediately see new tasks, messages, or can perform several other functions on your mobile while in transport or on the street, or in any other place.

Devices that support adaptive web design:

- desktop computers, notebooks, netbooks;

- tablets;

- mobile devices.

Browser that support adaptive web design:

- Google Chrome 4+;

- Mozilla Firefox 3.5+;

- Opera 9.5+;

- Safari 4+; 
- IE9+.

The main application of the automated system "CCSJP Manager" is a table of the management. Table of the management is a table which contains information about journals, namely: the names of all journals information on the index and a reference databases. According to this table, you can automatically build charts by selecting a journal and criteria. For charts can research the dynamics and forecasting of scientific publication, journal ranking, etc.

The report is a type of monologue speech, public, detailed, formal message to a question based on documentary evidence attraction. No one organization and no one thing cannot exist without reports and documentation. In writing they lost a lot of time for that has been developed for the automatic generation reports by predefined templates. Витративши меншу кількість часу на написання звітів - співробітник може виконувати інші справи, Employee may perform other cases when losing less time writing reports, which in turn will affect the efficiency.

The old software had a number of shortcomings that affect the work itself. After upgrading the software were corrected. One of the drawbacks was that when performing certain tasks need to update the page, the update takes time, notably on low equipment or slow Internet, and spent more traffic. This problem was solved by the approach AJAX. Chat heavily loaded, which is why it was processed personal message.

Conclusion

The developed software "CCSJP Manager" has improved the work of employees of the Coordinating Centre of Scientific Journals' Publishing of Odessa National Academy of Food Technologies. Automation has led to improved conditions and increase productivity, improve service quality, thus preserving the old and conquer new markets. But the current shortcomings prevented to achieve maximum effect.

It is through the old mistakes corrected software, the development of adaptive layout, the new design will contribute to achieving the maximum effect in the delivery of services editors of scientific periodicals ONAFT. Using the new approach, the development of new features and capabilities of software to help get the maximum efficiency of the employees of the center and distribute the labor force and dedicated work time.

\section{Referenses}

[1] Evernote. "Sohranyayte myisli i idei", evernote.com. [Online]. Available: https://evernote.com/intl/ru/;

[2] Organayzer LeaderTask | Planirovschik | Elektronnyiy ezhednevnik | Spisok del | Napominalka. - www.URL: http://www.leadertask.ru/;

[3] O. Yu. Sakaliuk, "Automation of Control of the Business Process of Publishing Scientific Journals", Automation of Technological and Business-Processes, vol. 8, no. 3, pp. 41-47, Sep, 2016;

[4] V. B. Yegorov, "Naukonetriya kak aspect kar'eri uchenogo," Ekonomika harchovoi promislovosti, vol. 25, no. 1, pp. 77-80, Mar, 2015;

[5] E.V.Taraseeva. (2014, Mar). "Improving the efficiency of business administration". fa.ru [Online]. Available: http://www.fa.ru/projects/mknrsa/skireports/3Менеджмент/Тарасеева Е.B.pdf ;

[6] ART Lemon. "Adaptivnaya verstka, preimuschestva i nedostatki adaptivnogo veb-dizayna", art-lemon.com. [Online]. Available: https://art-lemon.com/responsive-web-design;

[7] Web-siter. "Chto takoe dizayn sayta?", web-siter.com. [Online]. Available: http://www.web-siter.com/ru/webdesign.html;

[8] Web-siter. "Web-siter- sozdadim sayt, upravlyaemyiy Vami!”, web-siter.com. [Online]. Available: http://www.web-siter.com/ru/web-design.html;

[9] Kci. "Koordinaciyniy centr vidannya ONAHT. About us”, kci.onaft.edu.ua. [Online]. Available: http://kci.onaft.edu.ua/about;

[10] V. I. Shiryaev, Upravlenie biznes-protsessami: ucheb.-metod. posobie. M.: FiS, INFRA-M, 2009;

[11] Sistemyi menedzhmenta kachestva - Osnovnyie polozheniya i slovar, ISO 9000:2000;

[12] Sistemyi menedzhmenta kachestva - Trebovaniya, ISO 9001:2000. 